\title{
What is the Shape of the Multinationality-Performance Relationship?
}

Douglas E. Thomas, University of New Mexico Lorraine Eden, Texas A\&M University

ABSTRACT: Previous theoretical explanations and empirical analyses of the multinationality-performance relationship have produced mixed arguments and results. Linear and inverted U-shaped relationships have been theorized and confirmed empirically. Recent research has theorized that there is a three-stage, sigmoid relationship between multinationality and performance. We contribute to the debate by showing that the impact of multinationality depends on the time dimension incorporated in the performance measure; that is, the net benefits from multinationality are likely to be higher in the longer term. The results from our sample of US manufacturing multinationals indicate that there is a three-stage, sigmoid multinationality-performance relationship.

\section{INTRODUCTION}

Over the past three decades, international business and management scholars have sought to understand how international diversification through foreign direct investment (FDI) affects firm performance. However, previous research on the multinationalityperformance relationship has produced mixed arguments and results (e.g., Buhner, 1987; Kotabe, Srinivasan, \& Aulakh, 2002; Tallman $\& \mathrm{Li}, 1996)$. The most recent research has focused on explaining the shape of the relationship: linear, U- or inverted-U, or sigmoid; however, theoretical and empirical gaps continue to bedevil researchers.

This paper provides a fresh perspective on the multinationalityperformance debate. We first review

Dr. Douglas E. Thomas is an Assistant Professor in the Anderson Schools of Management at the University of New Mexico. His research interests include emerging market firms, strategic management in Latin America, and the internationalization of firms. E-mail: thomas@mgt.unm.edu Web Page: http://www.unm.edu/ thomasd

Dr. Lorraine Eden is Professor of Management at Texas A\&M University. Her research interests focus on the political economy of MNEs, specializing in transfer pricing, international taxation and regional integration.E-mail: leden@tamu.edu Web Page: http://cibs.tamu.edu/leden

A previous version of this paper was presented at the 2000 Academy of Management meeting in Toronto, Canada. 
recent literature on the debate, finding five different hypotheses about the shape of the multinationalityperformance relationship. We argue that there are three partial explanations for the confusing results in the literature (Annavarjula \& Beldona, 2000). First, the term

() 'multinationality' has different meanings. Conflicting results are partly due to different understandings

and proxy measures. Second, the

$\boldsymbol{\infty}$ theoretical benefits and costs of

(1) multinationality to an individual firm,

$ᄃ$ and how they are reflected in firm

$\cdot \bar{c}$ performance, are not well understood.

$\sim$ Third, the temporal dimension of the multinationality-performance has generally been ignored. For example, the differences between short-run and long-run performance have not been fully explored.

In the following sections, we develop a theoretical explanation of the multinationality construct, arguing it has three dimensions: foreign production presence, foreign market penetration and country scope. Next, we provide a clear outline of the benefits and costs of multinationality to firms in general. Finally, we argue

(1) that the impact of multinationality

ᄃ depends on the temporal dimension incorporated in the performance measure, that is, the net benefits from multinationality are likely to be higher in the longer term. We test our model on a sample of US manufacturing multinationals over the 1990-94 period, and present the somewhat surprising results. Finally, we offer some conclusions and guidance for future research.

\section{LITERATURE REVIEW}

The literature provides several theoretical explanations of the nature of the multinationality-performance relationship. Five general models positive and linear, positive but with diminishing returns, inverted-U shaped, and sigmoid - explaining the relationship have been presented by previous researchers. Empirically, these models have been tested to varying degrees. We review these models briefly below.

\section{Positive and Linear Model}

One stream of research on international diversification has hypothesized and found support for a positive, linear relationship (e.g., Grant, 1987; Grant, Jammine, \& Thomas, 1988; Han, Lee, \& Suk, 1998; Kim, Hwang, \& Burgers, 1989; Tallman \& $\mathrm{Li}, 1996)$. The theory and empirical results indicate that as firms expand internationally, there is a positive, linear impact on firm performance. More recent research finds that this positive, linear relationship is moderated by other factors (e.g., the firm's $R \& D$ and marketing capabilities (Kotabe et al., 2002)).

\section{Positive But Diminishing Returns Model}

From this perspective, multinationality has an initial positive impact on performance; however, over time, diminishing marginal returns set in. The slope of the curve is still positive (i.e., multinationality continues to have a positive impact on firm performance) but at a decreased rate (i.e., the benefits are not as great as 
they were initially) (Gomes \& Ramaswamy, 1999). Very little empirical research has specifically tested this relationship.

\section{U-shaped Relationship}

Other researchers have theorized and found evidence for a U-Shaped relationship between multinationality and firm performance (Ruigrok \& Wagner, 2003). Using organizational learning theory, Ruigrok and Warner (2003) find that firms initially experience negative performance when expanding internationally. Over time, however, as firms learn from their international experience, their performance becomes positive. Very little empirical research has examined this relationship.

\section{Inverted-U Relationship}

Another stream of research has argued (Hitt, Hoskisson, \& Ireland, 1994; Sullivan, 1994b) and found (Geringer, Beamish, \& daCosta, 1989; Gomes \& Ramaswamy, 1999; Hitt, Hoskisson, \& Kim, 1997) that there is a curvilinear (inverted-U) relationship between multinationality and firm performance. Over time, the positive impact on performance is outweighed by the costs of coordinating a widely dispersed network of international operations. In other words, the slope of the curve is initially positive and after reaching an apex, becomes negative. Hitt et al. (1997) argue that the relationship is inverted U-shaped because greater geographic dispersion increases the costs of coordinating, integrating and managing the multinational enterprise's (MNE) overall operations. They find an inverted Ushaped relationship between multinationality and performance, with the slope initially positive but turning negative at high levels of multinationality. Gomes and Ramaswamy (1999) argue that multinationality offers the ability to leverage scale economies, utilize home-based skills, competencies and resources, arbitrage differences in factor costs across countries, and spread the costs of product development. However, once the level of foreign operations becomes large, the MNE is forced to adopt more complex and costly organizational structures and move to less familiar settings where higher cultural diversity raises transactions costs. The results of their study indicate that the multinationality-performance relationship is nonlinear, first rising and then declining as costs eventually overtake the benefits of multinationality.

\section{Sigmoid Relationship}

Hitt et al. (1994) contend that the relationship is in the shape of an inverted-U. However, they point out that if one magnifies this relationship, there are peaks and valleys in the upward-sloping portion of the curve. As the firm expands internationally, it is involved in a process of minor downturns of performance and then upswings. Thus, they argue, "the actual shape of the curve is more accurately depicted as multiple waves" (p. 312).

Contractor et al. (2003) argue 
and find, using a sample of service firms, that there is a three-stage, sigmoid relationship between multinationality and performance. The nonlinear relationship is also examined by Riahi-Belkaoui (1998) (using the spline technique) to test the relationship between the foreign sales

(1) ratio and return on assets. The author $\simeq$ finds a negative relationship at low foreign sales ratio levels, which

$\boldsymbol{\omega}$ becomes positive and then finally

$\boldsymbol{\infty}$ negative as the foreign sales ratio (1) rises.

ᄃ What is the shape of the $-\infty$ multinationality-performance relationship? We contend that there are three partial explanations for the different theories and confusing results in the literature. First, the term 'multinationality' means different things to different people. This means that conflicting results are partly due to different understandings and proxy measures. Second, the theoretical benefits and costs of multinationality to firms, and how they are reflected in firm performance often conflict. Finally, we suggest that the temporal dimension of performance has not been adequately captured empirically.

(1) The multinationality-performance ᄃ relationship is different for short-run, $\vdash$ as compared to long-run, performance and must be accounted for in empirical measures.

The paper is organized in the following manner. First, we develop theory and hypotheses related to multinationality, its costs and benefits and the erstwhile ignored time dimension. Next, we test these hypotheses and discuss the empirical results. Finally, we offer some conclusions and guidance for future research.

\section{THEORY DEVELOPMENT What is Multinationality?}

Incomplete theoretical analysis of the multinationality construct has contributed to the mixed empirical results in studies of the multinationality-performance relationship. There are three key components to multinationality (Sullivan, 1994a, 1996). 1. Foreign market penetration, the dependence of the firm on foreign markets. 2. Foreign production presence or the degree to which the enterprise is engaged in production-based activities across borders (Annavarjula \& Beldona, 2000). 3. Country scope, which is the geographic range or breadth of the firm's international presence (Goerzen \& Beamish, 2003). The first two components, foreign market penetration and foreign production presence, represent the depth of the MNE's involvement abroad. Together they answer the question: What percent of the MNE's activities are conducted outside the home country? The third component, country scope, captures the breadth of multinationality. Country scope addresses the question: How wide is the global reach of the multinational enterprise? Because there has been an incomplete theoretical treatment of the multinationality construct, researchers have operationalized it in many different ways and generally paid inadequate attention to the particular dimension that their proxy 


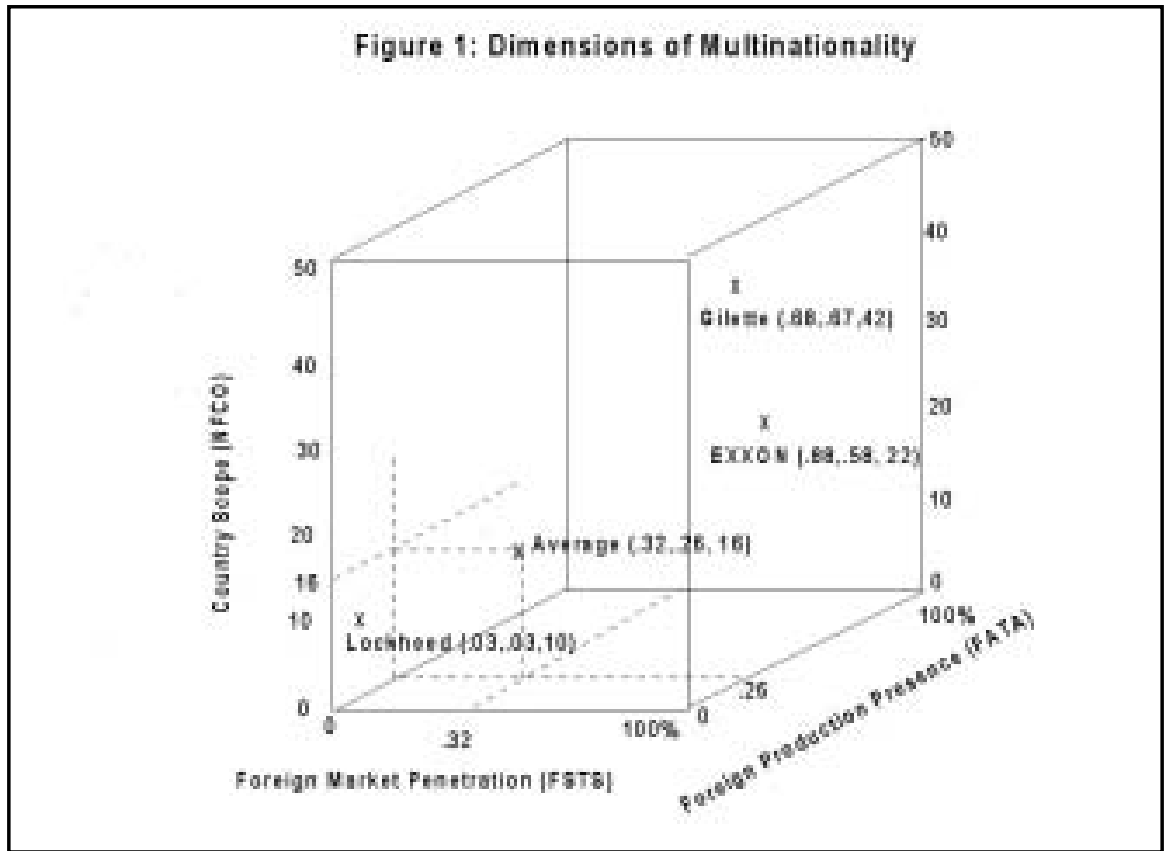

may only be capturing.

For example, multinationality has most often been measured using the foreign sales-total sales ratio (Sullivan, 1994a) which only captures one dimension of multinationality, foreign market penetration. Other common measures of multinationality include the foreign assets-total assets ratio and foreign employment-total employment ratio. We argue that foreign assets and employment ratios capture the foreign production presence dimension of multinationality. Finally two other variables that have been commonly used are number of foreign countries and number of foreign affiliates (Allen \& Pantzalis, 1996; Gomes \& Ramaswamy, 1999; Mishra \& Gobeli, 1998; Morck \& Yeung, 1991). These variables are good proxies for the third dimension of multinationality, country scope. Most previous research has used only one of these classes of variables and, therefore, limited multinationality to one dimension (exceptions include Allen \& Pantzalis, 1996; Daniels \& Bracker, 1989; Goerzen \& Beamish, 2003; Qian \& Li, 2002).

Figure 1 provides a visual, comparing two firms on different dimensions of multinationality. Lockheed is not very multinational when all three dimensions are considered. Exxon scores highly on both the foreign market penetration and foreign production presence dimensions but has relatively limited country scope. However, Gillette scores very highly on all three dimensions. This simple example makes it clear that all dimensions of multinationality must be considered theoretically and empirically in order to produce clear results in studies of the multinationality-performance 
relationship.

Hence, to truly capture multinationality all three dimensions should be measured: foreign market penetration, foreign production presence and country scope. A given firm may score high on one dimension but may be less multinational than (1) another that scores moderately on all $\simeq$ three dimensions. For example, Figure 1 provides some examples of three

$\boldsymbol{\omega}$ major U.S.-based manufacturing

$\boldsymbol{\infty}$ multinationals and their levels of

() multinationality using the three $\subset$ dimensions and appropriate proxies $\bar{\omega}$ (foreign sales-total sales ratio for foreign market penetration, foreign assets-total assets ratio for foreign production presence, and number of foreign countries for country scope).

We argue that firms will seek to operate at their optimal degree of

O breadth and depth of multinational - involvement (Allen \& Pantzalis, 1996).

๘ Given the existing breadth of the MNE C network, the enterprise can choose to allocate a higher or lower percent of its total activities to foreign operations and vice versa. Goerzen and Beamish (2003) find that multinational depth is negatively related to firm performance

(1) while breadth is positively related to

ᄃ firm performance. In contrast, Allen

$\vdash$ and Pantzalis (1996) find that there may be a tradeoff between breadth and depth. Their study found that performance levels were highest in firms with broad but not deep multinational networks and they concluded that "negative returns from multinationality can be attributed to overinvestment in 'within country' as opposed to 'across country' international expansion" (Allen \& Pantzalis, 1996: 645). In terms of our model, their work suggests that breadth and depth may have different impacts on firm performance. Hence, we argue that:

H1: The individual components of multinationality will have differing impacts on MNE performance; in particular, breadth of multinational involvement should be more positively related to performance than depth.

\section{Benefits and Costs of Multinationality}

MNEs have the ability to exploit sources of competitive advantage not available to domestic firms. These are potential benefits from multinationality because not all firms are able to capture them. The first general benefit is the ability to use foreign direct investment (FDI) to leverage differences and take advantage of opportunities between countries. As the level of international diversification increases the potential opportunities for the MNE also increase. We outline them below.

Differences in tastes, demands and income levels. MNEs can shift sales from low-income to high-income markets, generating higher profits on the firm's resources. Market-seeking FDI is designed to exploit profitable opportunities in higher income markets. As products become obsolete in high-income markets, FDI 
can be used to shift sales towards lowincome markets, extending the life of an obsolete product line. In international trade theory, these gains are called gains from exchange since they are generated by country-based differences in demand. We argue such differences can also be interpreted as offering FDI potential gains from exchange.

- Differences in factor endowments. Through FDI, a firm can reap gains from specialization by shifting production to lower cost locations and altering production techniques to take advantage of differences in factor abundances between countries. In international trade theory, these gains are called gains from specialization. Specialization gains are generated by either horizontally integrated FDI (producing the same product lines in two or more countries) or vertically integrated FDI (segmenting the stages along the value chain across countries). We call such investments resource seeking FDI, and these gains can be seen as the specialization gains from FDI.

- Differences in knowledgebased assets. Acquisition of knowledge-based assets also motivates FDI (Dunning, 1993). Researchers have argued (Kostova, 1999; Kostova \& Roth, 2002) and shown that (Hitt et al., 1997) MNEs with business units in more than one country can draw on the knowledge base in their foreign affiliates to improve their products and processes, generating worldwide organizational learning within the MNE's network.
Differences in government regulations. Investment shunting can be used to shift production to locations with lower taxes, higher subsidies or easier regulations. MNEs can set up financial affiliates in tax havens or move investments to avoid antidumping duties.

- Multinational flexibility. Managing multinational risk has long been considered a motivation for FDI (Rugman, 1976). In addition, researchers have argued that MNEs can take advantage of their multiple locations to flexibly adapt to changes/ shocks in the external environment (Kogut, 1984). For example, during the Mexican peso crisis in the 1990s, US subsidiaries in Mexico were able to shift their production from the depressed local market to the US market. Domestic Mexican firms, without access to US marketing and distribution networks, were not able to expand exports nearly as quickly as US subsidiaries.

Bargaining power. Large MNEs, due to their ability to move assets quickly between countries, have more bargaining power relative to location-bound actors, such as governments, trade unions and domestic firms.

Multinationality, however, is not a one-sided proposition. There are also costs because cross-border opportunities are not risk free. As the number of foreign countries in which the MNE operates rises, we expect the following firm-specific costs from multinationality. 
Costs and risks of multiple sources of value. Theoretical research indicates that one of the key characteristics differentiating MNEs from domestic firms is that MNEs operate with multiple sources of value (Sundaram \& Black, 1992). Different exchange rates between countries

(1) create foreign exchange risks for the $\simeq$ MNE. Foreign sales, the market value of the firm, and its ability to raise ( ) capital are negatively affected by

$\boldsymbol{c}$ translation exposure. The greater the

(1) number of foreign countries in which

$\therefore$ the MNE operates, the more foreign

$\bar{c}$ exchange risks to which the MNE may be sensitive. On the other hand, international diversification of markets and production locations may cushion the MNE from exchange rate shocks that are region specific (e.g., Asian currency crisis).

- Costs and risks of multiple ¥ levels of authority. As the MNE ( $)$ expands into more countries, it is ᄃ faced with higher cross-border $=$ transactions costs and higher

二 interaction costs with a wider variety $\supset$ and number of governments. Empirical $\sum$ research indicates that political risks may increase (Chase, Kuhle, \& (1) Walther, 1988). Additionally, it has $\subset$ been argued that there are increased difficulties to establishing legitimacy (Kostova \& Zaheer, 1999). On the other hand, as time passes and MNEs become established actors in host countries, the liability of foreignness should decrease at the individual affiliate level.

- Costs of greater cultural diversity. As the number of foreign markets and production locations increase, the MNE is faced with the costs of adapting to new and more heterogeneous cultures. Empirical research indicates that the liability of foreignness (Zaheer, 1995) increases as firms move to more culturally distant countries (Gomes \& Ramaswamy, 1999).

We concur with previous empirical research, which finds that there is a curvilinear relationship between multinationality and firm performance (Gomes \& Ramaswamy, 1999; Hitt et al., 1997). The benefits taper off while the costs rise as the degree of multinationality increases; the relationship between multinationality and firm performance should be non-linear, first rising and then declining. The costs and risks of multiple authorities, values and cultures should rise as their number and diversity increases. The relationship between multinationality and performance depends on a firm's ability to manage the complexities inherent in the internationalization process. We therefore hypothesize that:

\section{H2: The relationship} between multinationality and firm performance is curvilinear, first rising and then declining (an inverted- $U$ shape), reflecting the fact that multinationality carries both benefits and costs.

\section{The Role of Time}

Finally, the mixed results can at least be partially explained by 
neglecting the temporal dimension of the multinationality-performance relationship (exceptions include Aleson \& Escuer, 2001). Both the benefits and costs of multinationality can have different impacts in the short versus long term. Investments in $\mathrm{R} \& \mathrm{D}$, particularly in basic research, have a negative impact on short-run performance because costs are incurred well in advance of benefits. The anticipated returns from investments in intangible assets are better reflected in long-run performance. First mover advantages from entering foreign markets at an earlier stage than later entrants are reflected better by long-run anticipated returns than by short-run gains (e.g., Luo, 1998; Mascarenhas, 1992). Though empirical results are not completely consistent in this stream of literature, research generally indicates that First movers incur higher initial costs, reducing short-term financial performance but they typically gain higher market shares than latecomers.

As the enterprise becomes more multinational, it will have to adopt more sophisticated control mechanisms and organizational designs, raising the costs of operating the enterprise as a whole. Thus, costs of multinationality may also increase over time as shown in previous research (Hitt et al., 1997). At the same time, as firms internationalize they increasingly learn how to manage international operations (Barkema \& Vermeulen, 1998). We therefore hypothesize that the multinationalityperformance relationship has a time dimension. Because the benefits are more likely to be longer term in nature, relative to the costs, we hypothesize that:

H3: The benefits from multinationality for a firm are higher when measured in terms of long-run performance than short-run performance.

\section{METHODOLOGY}

Sample

We limited our sample to U.S. headquartered manufacturing firms (i.e., primary SIC between 2000-3999) included in the S\&P 500 (in COMPUSTAT) during the 1990-1994 period. Further, because we are focusing on the international operations of these companies, we eliminated firms that did not have at least one foreign affiliate. Missing data on several important variables for a few firms precluded their inclusion. Our final pooled cross-sectional, timeseries consisted of 151 firms followed over five years (i.e., sample size $=755$ observations). It should be noted that we are focusing on the impact of relative degree of multinationality on firm performance since all of our sample firms are multinational enterprises (i.e., they all have at least one foreign affiliate). Our multinationality variables are continuous ranging from zero (purely domestic firms) to one (100 percent internationalized firms). The average firm in our data set has approximately one-third of its sales and one-quarter of its assets overseas and operating affiliates in 16 foreign countries (see 
Figure 1).

\section{Firm Performance.}

Our analysis uses four measures of MNE performance: return on assets, return on equity, excess market value and average market

$>$ value. Initially, we started with two

(1) additional performance measures,

$\simeq$ return on sales and earnings per share. The Cronbach's alpha for the set of

の six measures was .8155 , suggesting

(S) they represent one common construct,

() firm performance. (Complete results

ᄃ from the factor analysis are available

$\bar{c}$ upon request from the authors.)

๘ However, a principal components

factor analysis shows that firm performance loads on two dimensions: the first dimension we call short-run

ช financial performance (return on ᄃ assets, return on equity, return on O sales, and earnings per share) and the - second, long-run expected market $\varpi$ performance (excess market value $\subset$ and average market value), with no unique factors. We chose to report return on assets and return on equity as our two measures of short-run profitability, rather than all four, to conserve space and because return

(1) on assets and return on assets are ᄃ commonly used profitability measures.

$\vdash$ Return on assets (ROA) is the most frequently used dependent variable in performance-multinationality studies (Gomes \& Ramaswamy, 1999; Sullivan, 1994a). Return on equity (ROE) is an alternative measure of financial performance, focusing on shareholders' equity. The numerator in both ratios is based on net income after tax and interest expenses.
Excess Market Value (EMV) is the ratio of market value plus the book value of debt minus total assets, all divided by total net sales (Allen \& Pantzalis, 1996). It measures the excess market valuation of the firm over and above the value of its physical assets. High ratios suggest the existence of intangible assets (e.g., technology, brand loyalty, superior managerial skills) and the implicit assessment of the firm's ability to capture the benefits of these intangibles in its long-run performance. Average market value (AMV), measured as market value divided by total assets, similarly focuses on market valuation.

EMV and AMV are future oriented, while ROA and ROE focus on last year's profitability. In this sense, EMV and AMV better capture the potential benefits from multinationality, particularly when the firm also has high ownership advantages. If this were the case, then one would expect that the returns to multinationality might be more closely tied to market-based performance measures than to financial ratios.

\section{Multinationality.}

We have argued above that multinationality has three components. The first is foreign market penetration, which we measure using the foreign sales-total sales ratio. The second component is foreign production presence measured by the foreign assets-total assets ratio. We considered both the total number of foreign affiliates and the number of countries where the MNE has 
foreign affiliates as a country scope variable. Since foreign affiliates can be concentrated in particular countries, the number of foreign countries provides a better representation of the global configuration of MNE activities.

We construct our index of multinationality, following Gomes and Ramaswamy's (1999) technique of employing a principal components analysis of the foreign sales ratio, the foreign assets ratio and the number of foreign countries to find their eigenvectors, and using these eigenvectors as weights. Given that these three components use differing scales it was important to standardize this variable (which we did) (Gomes \& Ramaswamy, 1999). The Cronbach's alpha for the three variables is .8172 , suggesting that our composite measure is valid.

\section{Control Variables.}

In order to isolate the impacts of multinationality on firm performance, it is important to include all other variables likely to affect performance. In the resource-based view of the firm (Barney, 1991), ownership advantages are intangible, inimitable and rare assets owned by the firm. In the OLI paradigm (Dunning, 1980, 1993), ownership advantages are similarly defined. Therefore, in our analysis we controlled for the impact that resources or ownership advantages have on firm performance.

We include three other firm-level controls for MNE resources. Our first proxy is the firm's technological intensity, measured by its $\mathrm{R} \& \mathrm{D}$ expenditures to sales ratio. As a proxy for resources arising from marketing expertise and brand loyalty, we use general administrative expenses divided by total sales. Since administrative costs can also proxy for the overhead or fixed costs associated with the firm's global activities, if there are firm-level economies of scale, administrative costs should decline as global sales increase. Hence, we included the ratio of administrative costs to total sales as a control variable. Our third control for ownership advantage is firm size, a proxy for economies of scale and scope. We use the natural log of total assets as our measure of firm size. We did a factor analysis of these three measures of ownership advantages; the resulting Cronbach's alpha value was .6538, suggesting that these three variables do load on a common construct, the competitive/ownership advantage of the MNE. In addition, the firm's debt-equity ratio is included as a control variable to capture a portion of firm's value and financial indebtedness. Finally, we also controlled for industry effects by including a set of industry dummy variables, based on the primary SIC code reported by each MNE: Food, Wood, Metal and Chemicals. We omitted one industry category, machinery.

\section{Data Analysis}

Because our sample is a panel data set, we tested our hypotheses using pooled, cross-section time-series regression techniques. First, we ran a series of F-tests in order to determine 
if there were significant year or firmspecific effects for which we needed to account. The results indicated significant period effects; hence, we included four year dummy variables in our regressions. We also standardized all variables (except the dependent and dummy variables) to

( ) mean 100 to correct for potential

$\Upsilon$ multicollinearity. Standardizing reduced the variance inflation factors

$\boldsymbol{\omega}$ (VIFs) for most variables to

$\boldsymbol{\omega}$ approximately 1.0. Our initial tests also

(1) indicated evidence of

$\subset$ heteroscedasticity but not

- $\boldsymbol{D}$ autocorrelation; therefore, we ran

OLS regressions with Whitecorrected standard errors to correct for heteroscedasticity providing robust variance estimates.

๘

\section{ᄃ RESULTS AND DISCUSSION}

O Descriptive statistics and - correlations for the standardized ( $)$ variables are presented in Table 1. Our $\subset$ regression results are presented in $\because$ Table 2, grouped by performance ニ measures. The first column in each $\supset$ group shows the results for each of $\Sigma$ the individual multinationality component measures (foreign sales

(1) ratio, foreign assets ratio, and number ᄃ of foreign countries). The second $\vdash$ column replaces these three variables with the single Multinationality index, and the third column introduces the squared term of the multinationality index (Multinationality Squared).

Previously, we argued that ROA and ROE are measures of short-term performance while EMV and AMV are long-term measures. In general, our results can be grouped based on these two sets of performance measures. Because our independent variables are centered at 100 , each beta coefficient should be interpreted as the conditional effects of a particular predictor at the mean of all the other predictors (Aiken \& West, 1991)

Hypothesis 1 focuses on the differing impacts that breadth and depth should have on multinationality. Table 2 shows that only Country Scope is positively and significantly related to performance across all four measures. The signs on Foreign Market Penetration are not significant in the short-run performance runs, and change direction in the long-run regressions. Foreign Production Presence is significant, and negative, only in the ROA regression. This suggests that breadth has more impact on performance than does depth, supporting hypothesis 1 .

We individually regressed quadratic forms of the three Multinationality variables on our four performance measures to see whether the individual Multinationality variables were linear in their relationships with firm performance. The results show that Foreign Market Penetration is significant and has a Ushaped relationship for all four performance measures (i.e., the coefficient on Foreign Market Penetration is significant and negative while the coefficient on Foreign Market Penetration-Squared is significant and positive). This suggests that higher foreign market penetration ratios are positively related to firm performance, at least after some 


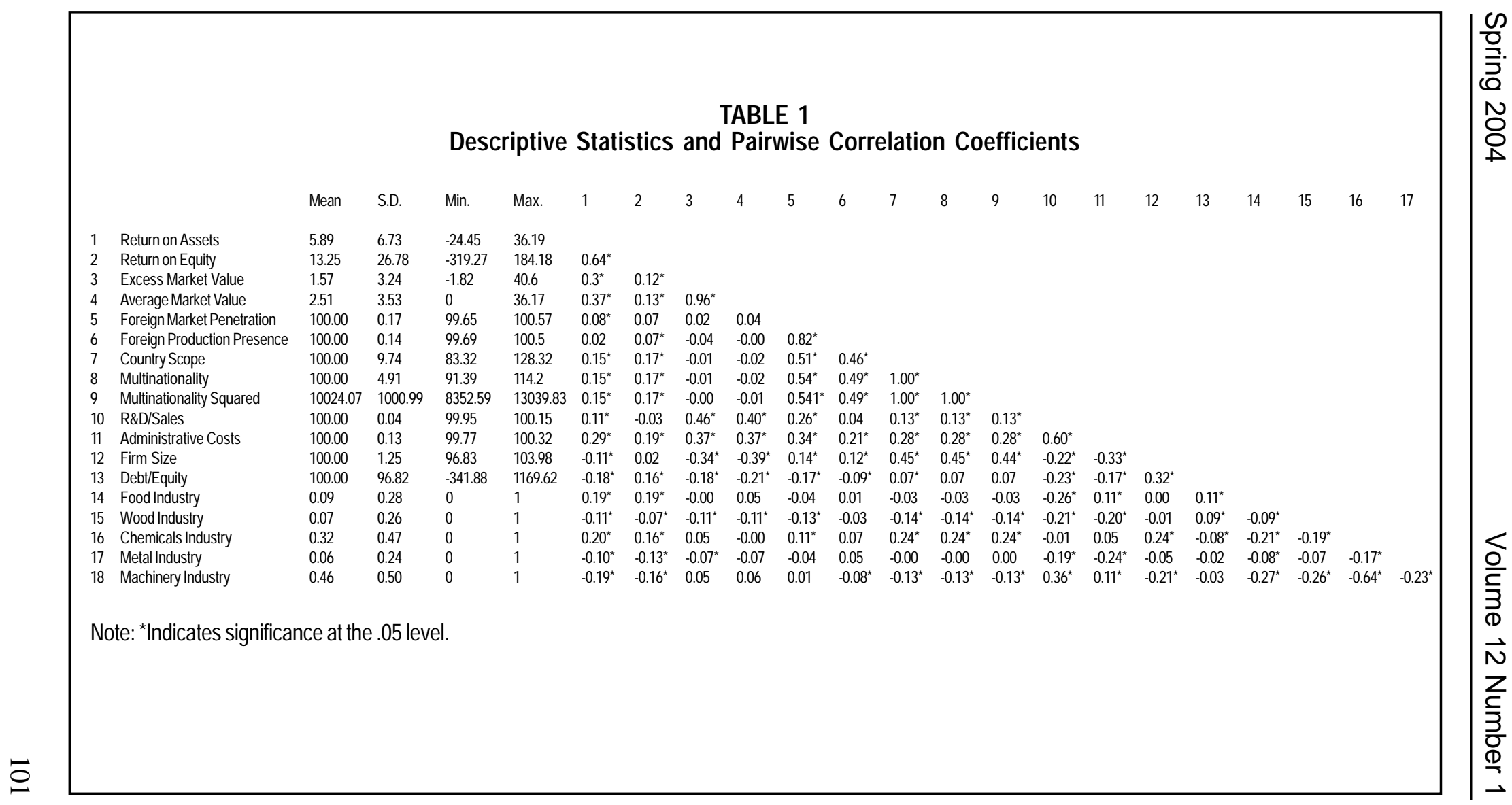

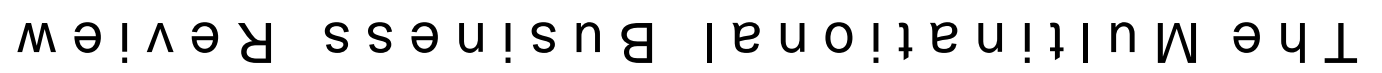


minimum level of foreign involvement. Foreign Production Presence has the traditional inverted-U shape for the ROA and ROE regressions, but is insignificant in the EMV and AMV regressions. The coefficients on Country Scope and Country Scope

$>$ Squared, on the other hand, are not

(1) significantly different from zero in all

$\simeq$ four regressions, implying that Country Scope is linearly related to

(S performance. Thus, we find limited

の support for our hypothesis that breadth

() (Country Scope) is more important for

$\subset$ firm performance than depth (Foreign

$\bar{c}$ Market Penetration and Foreign Production Presence).

Hypothesis 2 argues that there is an inverted-U relationship between multinationality and firm performance.

$\sigma$ Multinationality is significant and

$ᄃ$ positive in regressions using each of

O the four performance measures.

$\mp \quad$ However, when the squared term is

( $)$ added in the ROA and ROE runs,

ᄃ neither Multinationality nor

. Multinationality Squared is significant.

ニ The change in F-statistic is not

$\supset$ significant in either regression where

$\Sigma$ Multinationality Squared is added. We also tested (available on request), the

(1) change in $\mathrm{F}$ statistic when squared

ᄃ terms for the three individual

$\vdash$ multinational components are added to the 'Multinationality Variables' regression (column 1). The change in the F-statistic is significant at the 5\% level for both the ROA and ROE regressions. Taken together, these results suggest that the relationship between the multinationality index and financial performance is positive, but linear, even though individual components may have a nonlinear relationship with financial performance.

In the EMV and AMV regressions, when the squared term is added, the sign on Multinationality switches to negative, while Multinationality Squared is positive. The change in F statistic is significant at the .001 level, supporting hypothesis 2 that the relationship is nonlinear. However, the relationship appears to be U-shaped for EMV and AMV, first falling and then rising. In other words, multinationality initially has a negative impact on firm performance and then, as firms continue to expand internationally, the impact becomes positive. The change in $\mathrm{F}$ statistic when squared terms for the three individual multinational components are added to the 'Multinationality Variables' regression (column 1) is significant at the .001 level for both EMV and AMV.

Looking specifically at the third regression for EMV, the coefficient on Multinationality is -2.2487 and for Multinationality Squared is +0.01188 , implying a slope of dEMV/ dMultinationality $=-2.2487+$ 2(.01188) Multinationality. Substituting in different values of Multinationality, we see that the relationship is Ushaped, bottoming out at Multinationality $=94.6$. Hence, our Ushape is increasing, not decreasing, in Multinationality, contrary to other studies finding an inverted-U relationship and contrary to Hypothesis 2. Employing the same technique for the AMV regression suggests a similar pattern. We 


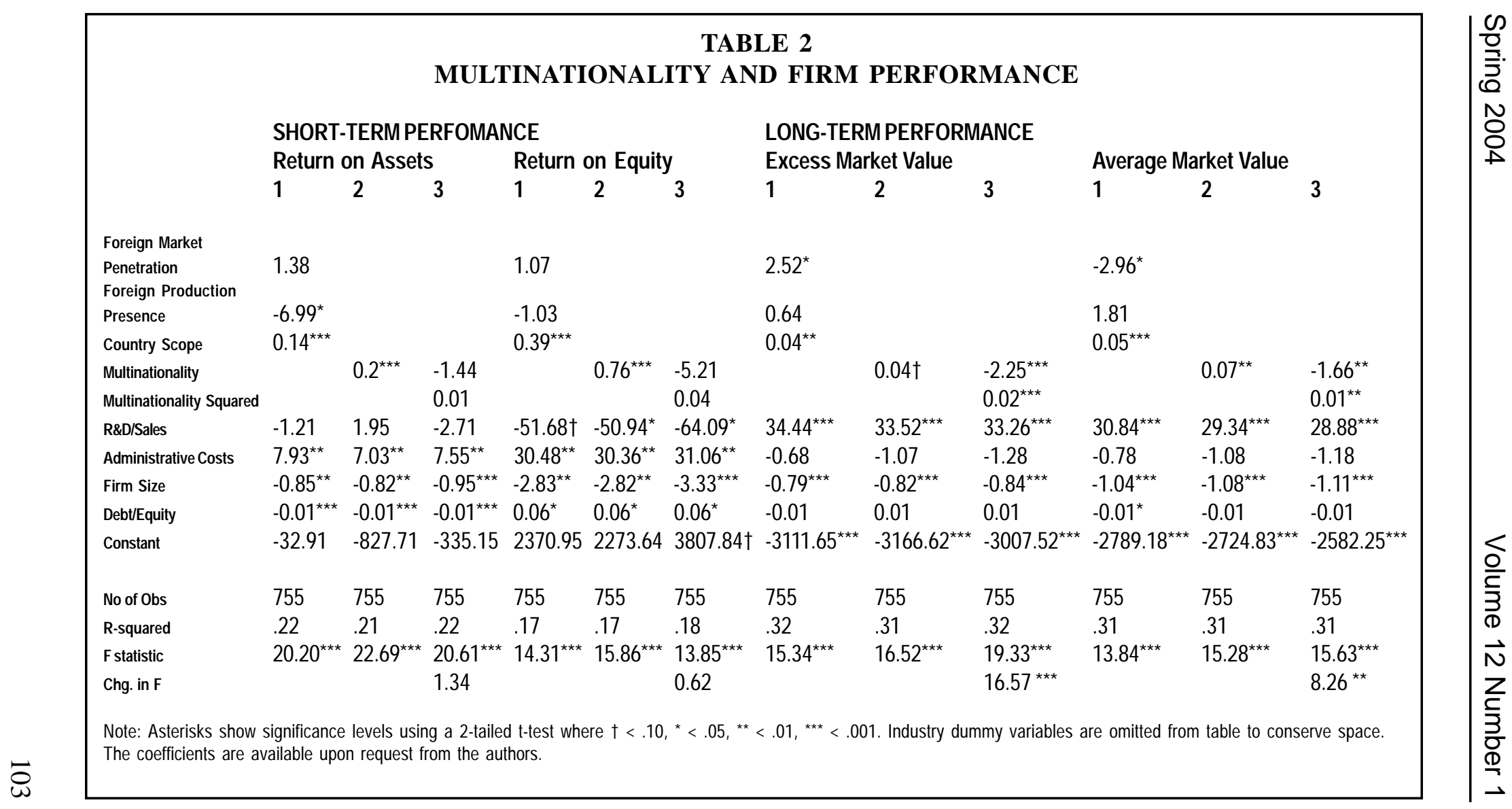

мә!^әу ss 
illustrate the EMV-Multinationality relationship in Figure 2.

Hypothesis 3 focuses on the differing impact that multinationality should have on firm performance with respect to time. Some evidence of a difference is already suggested above, where the ROA and ROE regressions

(1) show a positive but linear relationship

$\simeq$ between multinationality and performance, while the EMV and

の AMV regressions show a U-shaped

の relationship. We also conducted a test

(1) of Hypothesis 3 using spline analysis.

C Table 3 shows the beta coefficients

$\bar{\omega}$ for the four performance variables, with Multinationality split into three segments (Riahi-Belkaoui, 1998).

The spline coefficients in the ROA and ROE regressions are ช significant (and positive) in only one $\subset$ segment, suggesting a linear O relationship between multinationality च and these performance ratios. The (v) spline coefficients in the EMV and $\subseteq$ AMV regressions, on the other hand, .$\quad$ are significant and first positive, then - negative, and then positive. This suggests a sigmoid multinationalityperformance relationship. Since the coefficients are the slopes of the

(1) EMV-Multinationality relationship,

ᄃ conditional on all other variables being

$\vdash$ at their mean values, these EMV regressions provide further evidence that multinationality positively affects market performance in the long-term. In other words, multinationality is nonlinear and increasing in its relation with EMV and AMV, but not with ROA or ROE.

Our results are surprising given that other studies have found a non- linear, but inverted-U shaped, relationship between multinationality and performance. However, they are consistent with hypothesis 3 , which argues that the impact of multinationality on firm performance is time dependent. We argued that EMV and AMV measure long-run expected performance of the firm, taking into account both the intangible and tangible assets of the firm. Both are proxies for Tobin's q, which captures the potential rents from the firm's intangible assets. ROA and ROE, on the other hand, are more directly related to short-run financial performance based on the firm's capital assets. That is, EMV and AMV are future oriented, while ROA and ROE focus on last year's profitability. In this sense, EMV and AMV better capture the potential benefits from multinationality, particularly when the firm also has high ownership advantages. We illustrate this argument in Figure 3 below.

Considering the results from all of the tests together, we find that there is a non-linear, three-stage sigmoid relationship between multinationality and performance. Thus, the relationship suggested in Figure 2 is only part of the picture (the last two stages). Figure 3 indicates the totality of the multinationalityperformance relationship (all three stages). Initially, multinationality has a positive impact on performance; however, in time, the costs of multinationality outweigh the benefits. But in the long-run, multinationality leads to positive performance. Our 
Figure 2: The Relaticenship between EMV and Multinationality

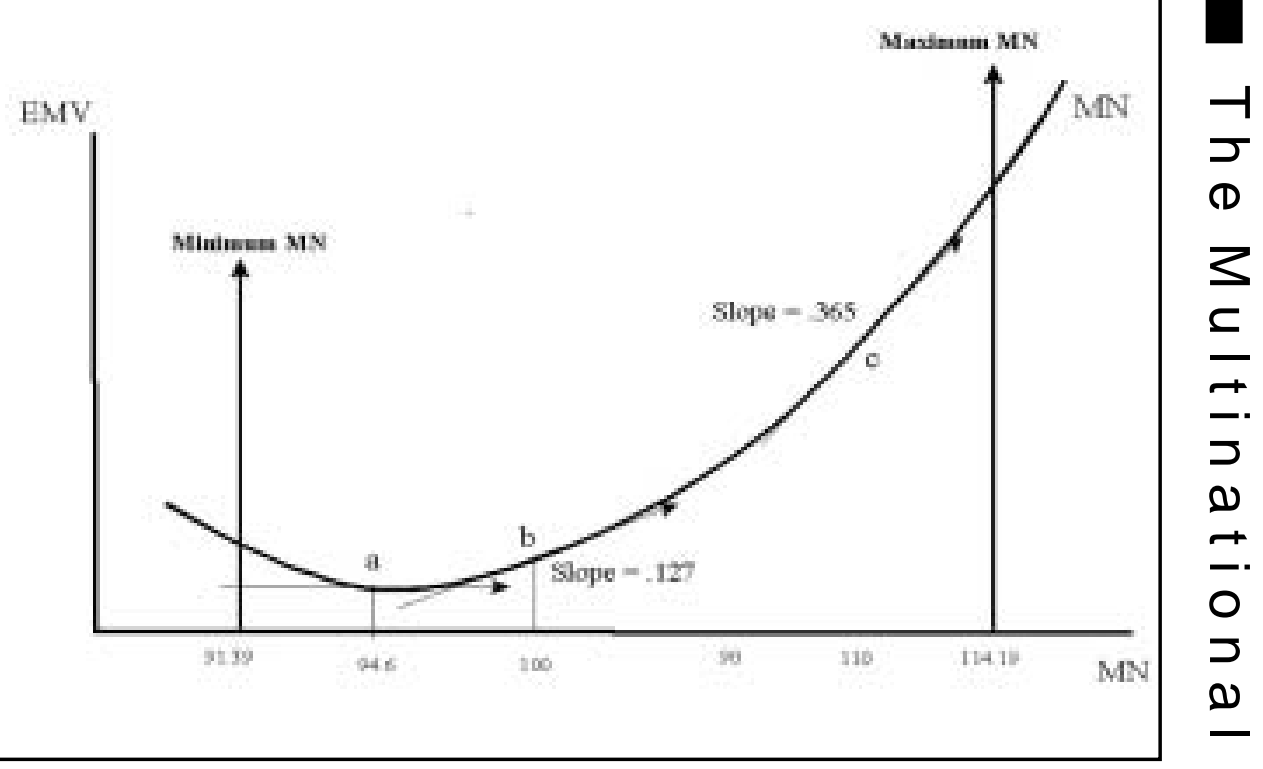

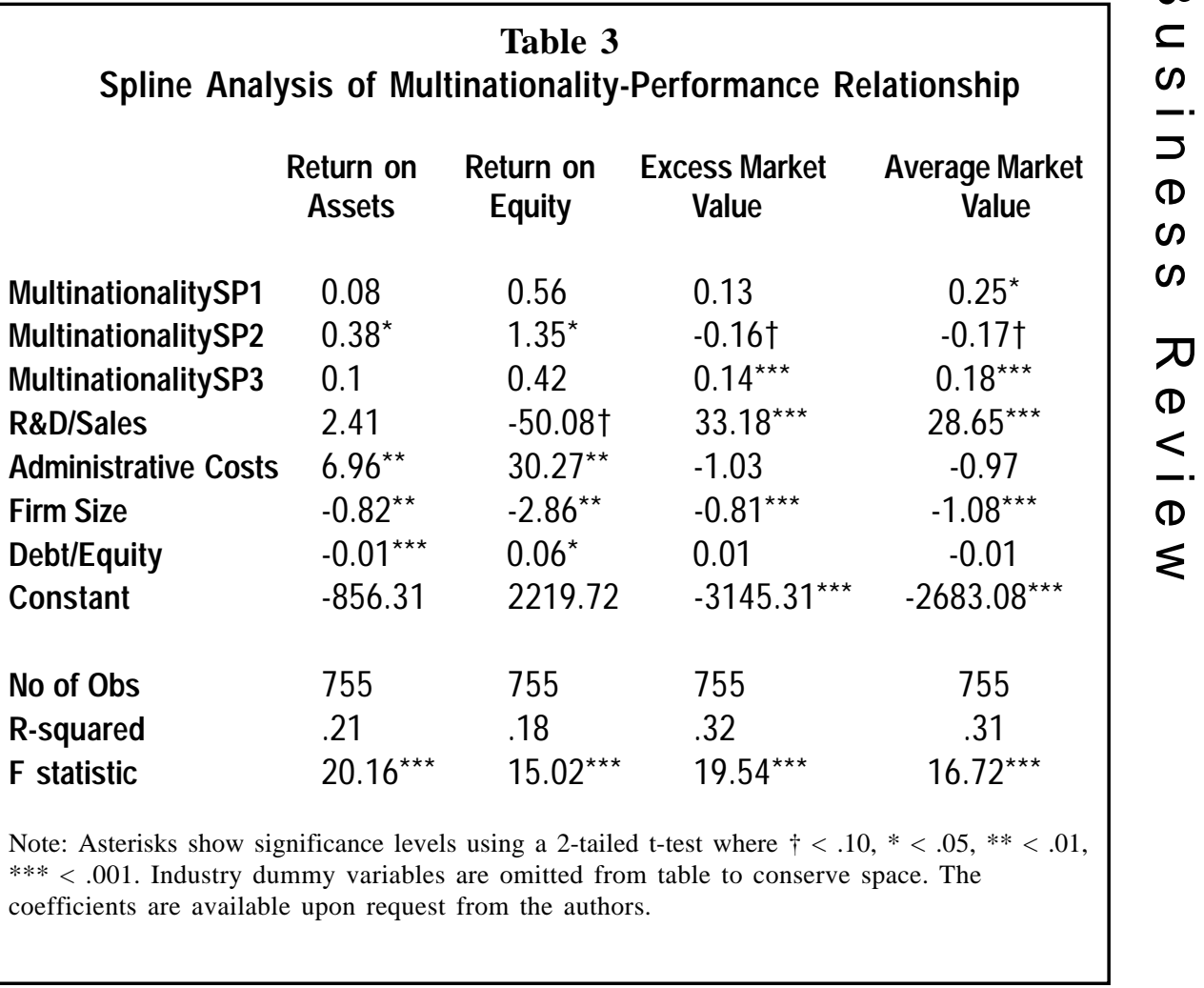


results suggest that the long-run expected market returns might be much larger than the short-run actual financial returns to multinationality, and that even the largest US manufacturing multinationals may not have exhausted the returns from increasing the depth and breadth of

() their international operations.

ฯ

\section{CONCLUSION}

$\omega$

(D) unraveling the debate over the shape

() of the multinationality-performance

$\subset$ relationship. Previous research has

$-\bar{c}$ produced mixed results, with some studies finding a positive, linear relationship and more recent ones a sigmoid relationship. We argued that there were three partial explanations

$\sigma$ for the confusing results in the

ᄃ literature. First, the term

ㅇ 'multinationality' means different

- things to different people, so that

(v conflicting results are partly due to

$\subseteq$ different understandings and proxy measures. Second, the theoretical benefits and costs of multinationality to firms, and how they are reflected in firm performance, are not well understood. Third, we argued that time

() matters. The multinationalityᄃ performance relationship is different

$\vdash$ for short-run, as compared to longrun, performance.

Our results provide limited support for the hypothesis that the construct is composed of several dimensions and that breadth has more impact than depth on firm performance. Future research on the multinationality-performance relationship should be careful to consider and explain carefully the dimensions of multinationality in both empirical and theoretical studies.

Perhaps the most important finding of our study is that the multinationality-performance relationship is non-linear but most importantly in the long term. Indeed, our results indicate that there are initial benefits from multinationality that are then outweighed by rising costs of going abroad; however, over time, the long-run benefits dominate the costs, suggesting a significant, positive relationship between multinationality and long-run market performance.

Based on our empirical results, we speculate that most US manufacturing multinationals may not have reached their optimal degree of multinationality; there are still additional gains from international diversification to be garnered by US multinationals. To the degree that this is true, the future is very bright for the internationalization of firms. At the same time, we do not know, based on the results of this study, how long it may actually take for firms to receive the greatest benefits from globalization. Much more empirical and theoretical research is needed to better understand this relationship. We need to know, for example, how long it might take for the benefits to outweigh the costs. In order to gain this understanding, longitudinal studies over a much longer time horizon are still needed. In addition, we do not know how future protectionist measures and backlashes to globalization may affect the ability of multinationals to fully reap the benefits 
Figure 3

Multinationality and Short and Long Run Firm Performance

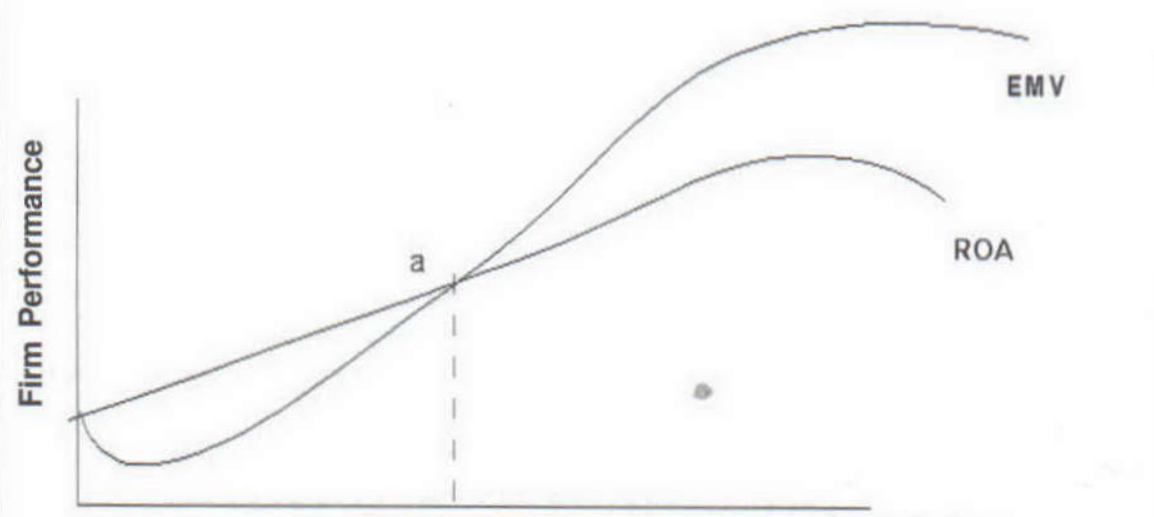

MN Index

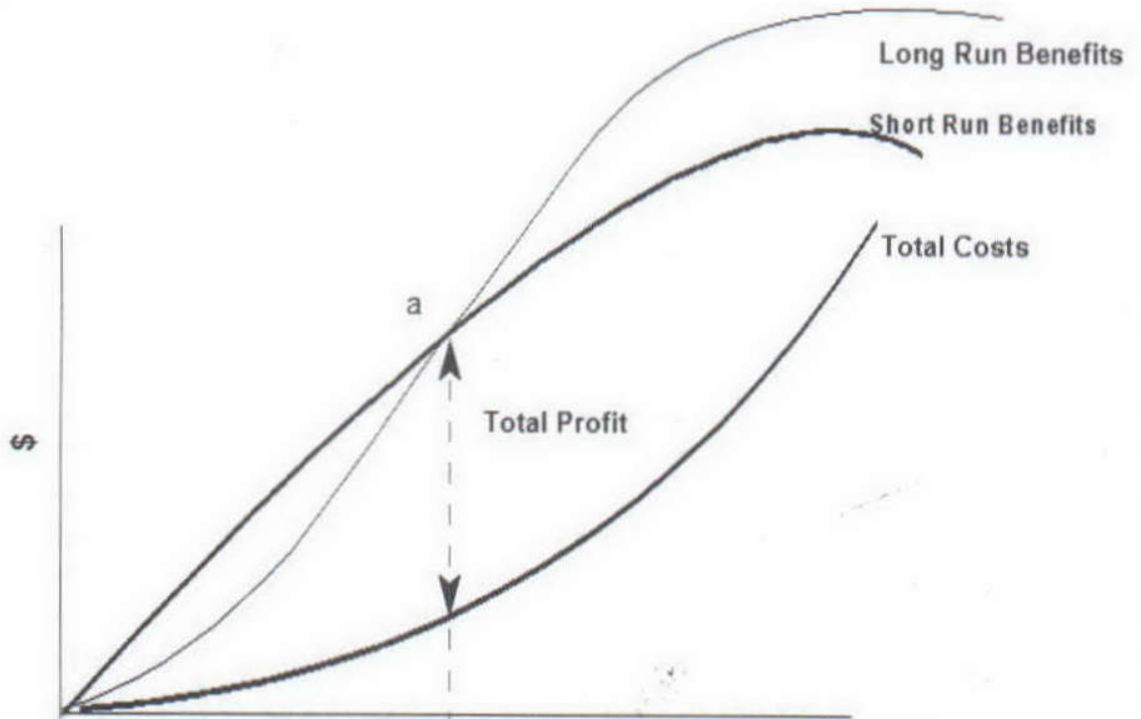

MN Index 
of internationalization.

Our results make an important contribution to the international business and management literature by demonstrating that the multinationality-performance relationship is much different than what has traditionally been theorized.

(1) Instead of being a simple linear or $\simeq$ even curvilinear relationship, the multinationality-performance

() relationship contains multiple peaks

$\boldsymbol{\omega}$ and valleys as organizations adapt to

(1) the constant challenges and $\subset$ opportunities that international $-\bar{c}$ diversification presents. This has broader implications for strategic management because so often the temporal dimension of strategies is not well emphasized.

These results have important implications for managers. The business press, management consultants, and others have trumpeted the benefits of globalization and international diversification for two decades now. On the other hand, strong opposition to the globalization of firms and markets has been expressed as well. Our study highlights that it is over the longer term that the returns from multinationality to firms is shown in stronger market performance. These results indicate that harvesting real benefits from international diversification may require patience on the part of managers.

Future research should continue to explore the temporal dimension of the multinationality-performance relationship. For example, studying the effects of international diversification on firm performance over longer time horizons (e.g., thirty or more years) could further validate the results of this study. In addition, researchers should explore this relationship in contexts other than U.S. based multinationals. For example, it is important to determine if the results of this study are applicable to emerging market multinationals.

\section{REFERENCES}

Aiken, L. S., \& West, S. G. 1991. Multiple regression: Testing and interpreting interactions. Newbury Park, CA: Sage Publications.

Aleson, M. R., \& Escuer, M. A. E. 2001. The effect of international diversification strategy on the performance of Spanish-based firms during the period 1991-1995. Management International Review, 41:291-315.

Allen, L., \& Pantzalis, C. 1996. Valuation of the operating flexibility of multinational corporations. Journal of International Business Studies, 27: 633-653.

Annavarjula, M., \& Beldona, S. 2000. Multinationality-performance relationship: A review and reconceptualization. International Journal of Organizational Analysis, 8: 48-67.

Barkema, H. G., \& Vermeulen, F. 1998. International expansion through start-up or acquisition: A learning perspective. Academy of Management Journal, 41: 7-26.

Barney, J. B. 1991. Firm resources and sustained competitive advantage. Journal of Management, 17: 99-120. Buhner, R. 1987. Assessing international diversification of West German corporations. Strategic Management Journal, 8: 25-37. 
Chase, C. D., Kuhle, J. L., \& Walther, C. H. 1988. The relevance of political risk in direct foreign investment. Management International Review, 28:31-38.

Contractor, F. J., Kundu, S. K., \& Hsu, C. C. 2003. A three-stage theory of international expansion: The link between multinationality and performance. Journal of International Business Studies, 34: 5-18.

Daniels, J. D., \& Bracker, J. 1989. Profit performance: Do foreign operations make a difference? Management International Review, 29: 46-56.

Dunning, J. H. 1980. Toward an eclectic theory of international production: Some empirical tests. Journal of International Business Studies, 11: 9-31.

Dunning, J. H. 1993. Multinational enterprises and the global economy. Harlow, UK: AddisonWesley.

Geringer, J. M., Beamish, P. W., \& daCosta, R. C. 1989. Diversification strategy and internationalization: Implications for MNE performance. Strategic Management Journal, 10: 109-119.

Goerzen, A., \& Beamish, P. W. 2003. Geographic scope and multinational enterprise performance. Strategic Management Journal, 24: 12891306.

Gomes, L., \& Ramaswamy, K. 1999. An empirical examination of the form of the relationship between multinationality and performance. Journal of International Business Studies, 30: 173-188.

Grant, R. M. 1987. Multinationality and performance among British manufacturing companies. Journal of International Business Studies, 18: 79-89.
Grant, R. M., Jammine, A. P., \& Thomas, H. 1988. Diversity, diversification, and profitability among British manufacturing companies, 1972-84. Academy of Management Journal, 31:771-801.

Han, K. C., Lee, S. H., \& Suk, D. Y. 1998. Multinationality and firm performance. Multinational Business Review, 6(2): 63-70.

Hitt, M. A., Hoskisson, R. E., \& Ireland, R. D. 1994. A mid-range theory of the interactive effects of international and product diversification on innovation and performance. Journal of Management, 20: 297-326.

Hitt, M. A., Hoskisson, R. E., \& Kim, H. 1997. International diversification: Effects on innovation and firm performance in product-diversified firms. Academy of Management Journal, 40: 767-798.

Kim, W. C., Hwang, P., \& Burgers, W. P. 1989. Global diversification strategy and corporate profit performance. Strategic Management Journal, 10: 45-57.

Kogut, B. 1984. Normative observations on the international value-added chain and strategic groups. Journal of International Business Studies, 15: 151-167.

Kostova, T. 1999. Transnational transfer of strategic organizational practices: A contextual perspective. Academy of Management Review, 24: 308-324.

Kostova, T., \& Roth, K. 2002. Adoption of an organizational practice by subsidiaries of multinational corporations: Institutional and relational effects. Academy of Management Journal, 45: 215-233.

Kostova, T., \& Zaheer, S. 1999. Organizational legitimacy under conditions of complexity: The case of the multinational enterprise. 
Academy of Management Review, 24: 64-81.

Kotabe, M., Srinivasan, S. S., \& Aulakh, P. S. 2002. Multinationality and firm performance: The moderating role of R\&D and marketing capabilities. Journal of International Business Studies, 33: 79-97.

Luo, Y. 1998. Timing of investment and international expansion

Morck, R., \& Yeung, B. 1991. Why investors value multinationality. Journal of Business, 64: 165-187.

Qian, G., \& Li, J. 2002. Multinationality, global market diversification and profitability among the largest US firms. Journal of Business Research, 55:325-335.

Riahi-Belkaoui, A. 1998. The effects of the degree of internationalization on firm performance. International Business Review, 7: 315-321.

Rugman, A.-M. 1976. Risk reduction by international diversification. Journal of International Business Studies, 7: 75-80.

Ruigrok, W., \& Wagner, H. 2003. Internationalization and performance: An organizational learning perspective. Management International Review, 43: 63-83.

Sullivan, D. 1994a. Measuring the degree of internationalization of a firm. Journal of International Business
Studies, 25: 325-342.

Sullivan, D. 1994b. The "threshold of internationalization": Replication, extension, and reinterpretation. Management International Review, 34: 165-186.

Sullivan, D. 1996. Measuring the degree of internationalization of a firm: A reply. Journal of International Business Studies, 27: 179-192.

Sundaram, A. K., \& Black, J. S. 1992. The environment and internal organization of multinational enterprises. Academy of Management Review, 17: 729-757.

Tallman, S., \& Li, J. 1996. Effects of international diversity and product diversity on the performance of multinational firms. Academy of Management Journal, 39: 179-196.

Zaheer, S. 1995. Overcoming the liability of foreignness. Academy of Management Journal, 38: 341-363. 